Review

\title{
Credibility of the Neutrophil-to-Lymphocyte Count Ratio in Severe Traumatic Brain Injury
}

\author{
Dorota Siwicka-Gieroba *(D) and Wojciech Dabrowski
}

check for

updates

Citation: Siwicka-Gieroba, D.;

Dabrowski, W. Credibility of the

Neutrophil-to-Lymphocyte Count

Ratio in Severe Traumatic Brain

Injury. Life 2021, 11, 1352.

https://doi.org/10.3390/

life11121352

Academic Editors: Huang-Ping Yu and Fu-Chao Liu

Received: 1 November 2021

Accepted: 3 December 2021

Published: 7 December 2021

Publisher's Note: MDPI stays neutral with regard to jurisdictional claims in published maps and institutional affiliations.

Copyright: (C) 2021 by the authors Licensee MDPI, Basel, Switzerland. This article is an open access article distributed under the terms and conditions of the Creative Commons Attribution (CC BY) license (https:// creativecommons.org/licenses/by/ $4.0 /)$
Department of Anaesthesiology and Intensive Care, Medical University of Lublin, 20-059 Lublin, Poland; w.dabrowski5@yahoo.com

* Correspondence: dsiw@wp.pl

\begin{abstract}
Traumatic brain injury (TBI) is one of the leading causes of morbidity and mortality worldwide. The consequences of a TBI generate the activation and accumulation of inflammatory cells. The peak number of neutrophils entering into an injured brain is observed after $24 \mathrm{~h}$; however, cells infiltrate within 5 min of closed brain injury. Neutrophils release toxic molecules including free radicals, proinflammatory cytokines, and proteases that advance secondary damage. Regulatory $\mathrm{T}$ cells impair $\mathrm{T}$ cell infiltration into the central nervous system and elevate reactive astrogliosis and interferon- $\gamma$ gene expression, probably inducing the process of healing. Therefore, the neutrophilto-lymphocyte ratio (NLR) may be a low-cost, objective, and available predictor of inflammation as well as a marker of secondary injury associated with neutrophil activation. Recent studies have documented that an NLR value on admission might be effective for predicting outcome and mortality in severe brain injury patients.
\end{abstract}

Keywords: TBI; brain injury; neutrophils; lymphocytes; NLR; mortality

\section{Introduction}

Traumatic brain injury (TBI) is one of the major causes of morbidity and mortality worldwide; it is a health problem that affects all ages and populations. Brain injury has two stages: primary injury due to mechanical damage and secondary injury that corresponds to a decrease in blood flow and oxygenation, edema, ischemic reperfusion injury, metabolic and endocrine dysfunction, oxidative stress, and impairment of ionic homeostasis. All these processes lead to activation and accumulation of inflammatory cells. The mechanism of inflammatory damage is still under investigation (Figure 1).

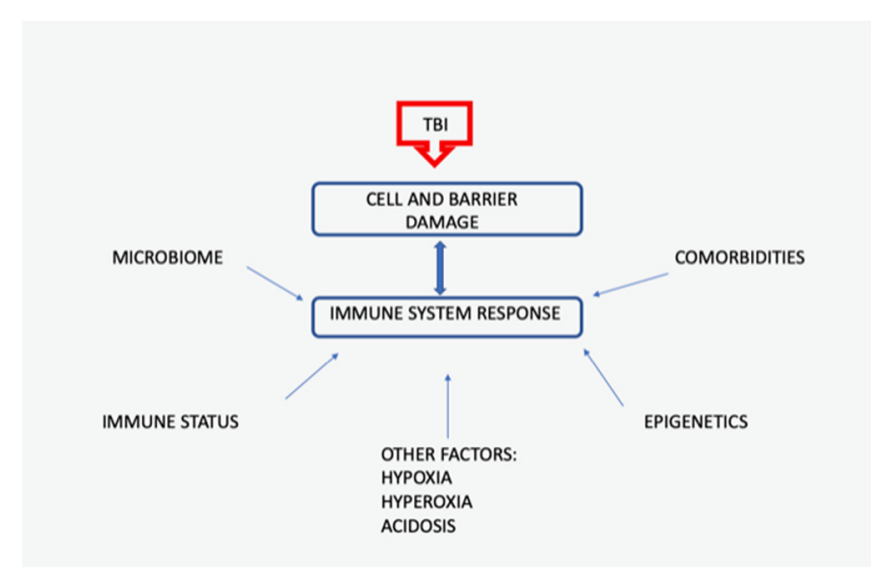

Figure 1. Selected factors that influence the immune response in TBI. The activity of the immune system depends on the homeostasis of the organism as well as on variable external factors; TBItraumatic brain injury. 
The immune cells, i.e., neutrophils, monocytes, as well as astrocytes and microglia, are crucial elements of acute cellular reactions. The inflammatory reaction after a TBI may be stimulated by damage associated with molecular patterns rapidly released after an injury. Disruption of the blood-brain barrier (BBB) is observed early after a TBI incident and a significant elevation in leukocyte migration aggravates a focal inflammatory response, leading to a worsening of secondary damage [1].

Several studies have reported that neutrophil count is usually elevated and lymphocytes present no significant changes during the acute phase after a brain injury [2,3]. These inflammation responses are closely correlated with poor outcomes for patients after injury.

The purpose of this article is to review the association between neutrophils and leukocytes and their neutrophil-to-lymphocyte ratio (NLR) related to outcome and mortality after a brain injury [4].

\section{Neutrophils in TBI}

Neutrophils, one of the crucial components of the innate immune system, mature from granulocyte/monocyte progenitor cells in the bone marrow. Neutrophils are infrequently observed in the central nervous system because of the BBB [5]. In a healthy person, a tight junction between endothelial cells stops neutrophils from penetrating the central nervous system [6]. A small number of neutrophils and other immune cells have been observed in cerebrospinal fluid (CSF), meninges, and pia membranes [6,7]. Under initial conditions, neutrophils exist only few hours. Although, human neutrophils in vivo may live more than 5 days [8]. Importantly, aged neutrophils present markers of a proinflammatory phenotype and other important changes as elevation of CXCR4 [9]. These processes are improving the neutrophils removal from circulation [10]

It is worth mentioning that neutrophils' aging process is strongly controlled by microbiome [11]. Neutrophils are eliminated by macrophages in the spleen or liver, through apoptosis. Importantly, neutrophils activation can be changed by the surrounding environmental conditions, for example, hypoxia increases the lifespan of neutrophils [12].

Neutrophils have special defensive mechanisms for eliminating pathogens, which include matrix metalloproteinases (MMPs), myeloperoxidase, neutrophils elastase (NE), neutrophils gelatinase-associated lipocalin, and SGP28 [13,14]. Also, a neutrophil's extracellular trap (NET) is another important protective mechanism [15]. Zhu et al. documented that NETs activation in the paraventricular nucleus is connected with sympathetic hyperactivity after traumatic brain damage. In animal model authors observed that reactive oxygen species in the paraventricular nucleus activate formation and chemotaxis of NETs which finally relate to the activation of microglia cells and increased secretion of IL- $1 \beta$ via the hippo/MST1 pathway [16].

In addition, neutrophils can intensify their own activation through an autocrinedependent manner including leukotriene B4, IL-18 and platelet-activating factor [10]. Therefore, these cells are often phagocytosed or suppressed by macrophages or lymphocytes, because of the possibility of generating tissue injury [17]. Moreover, neutrophils release toxic molecules including reactive oxygen species (ROS), nitrous oxide (NOS), NADPH oxidase, proinflammatory cytokines, and proteases, which advance secondary damage after recruitment to an injured central nervous system (Table 1).

Table 1. Selected neutrophil-derived interleukins and chemokines, their functions in a brain injury and potential therapeutic methods of treatment. Neutrophils release toxic molecules including reactive oxygen species (ROS), nitric oxide synthase (NOS), NADPH oxidase, proinflammatory cytokines, and proteases, which advance secondary damage; BBB-blood brain barrier; CXCL—chemokine (C-X-C motif) ligand; IL-interleukin; JNK-c-Jun N-terminal kinase; NLRP-nucleotidebinding oligomerization domain; TGF-transforming growth factor.

\begin{tabular}{cccc}
\hline Name & Effects & Therapeutic METHODS & References \\
\cline { 1 - 2 } IL-1 $\alpha$ & Interleukins & $\begin{array}{c}\text { Recombinant human IL-1Ra, NLRP3 inhibitor, } \\
\text { Mesenchymal stem/stromal cells therapy, ketamine }\end{array}$ & [18-20] \\
\hline
\end{tabular}


Table 1. Cont.

\begin{tabular}{|c|c|c|c|}
\hline Name & Effects & \multirow{2}{*}{ Therapeutic METHODS } & \multirow{2}{*}{ References } \\
\hline \multicolumn{2}{|r|}{ Interleukins } & & \\
\hline IL-1 $\beta$ & Apoptosis; secretion of IL- 6 and IL- 8 by astrocytes & $\begin{array}{l}\text { Melatonin MT1/MT2 receptor agonist, NLRP3 } \\
\text { inhibitor, JNK inhibitor, oxytocin, Baicalin, } \\
\text { Xanthohumol, ketamine, Serp-1 }\end{array}$ & [18-25] \\
\hline IL-3 & Inhibition of secondary degeneration & $\begin{array}{l}\text { Interleukin-3 (IL-3) and granulocyte/macrophage } \\
\text { colony-stimulating factor (GM-CSF) }\end{array}$ & [26] \\
\hline IL-4 & $\begin{array}{c}\text { Matter integrity promotion; long-term } \\
\text { neurological recovery }\end{array}$ & $\begin{array}{c}\text { Melatonin MT1/MT2 receptor agonist, Mesenchymal } \\
\text { stem/stromal cells therapy }\end{array}$ & {$[20,22]$} \\
\hline IL-6 & Nerve growth factor production & $\begin{array}{c}\text { NLRP3 inhibitor, TGF- } \beta 1 \text { infusion, metformin, } \\
\text { melatonin, Vitamin D, JNK inhibitor, exosomes, } \\
\text { lipopolysaccharide (LPS) injection, mesenchymal } \\
\text { stem/stromal cells therapy }\end{array}$ & {$[18-23,27-29]$} \\
\hline IL-7 & Induction of gliosis & Lipopolysaccharide (LPS) injection & [30] \\
\hline IL-9 & excitotoxic damage; destruction of BBB & & [31] \\
\hline IL-10 & Downregulation of pro-inflammatory cytokines & $\begin{array}{l}\text { Melatonin MT1/MT2 receptor agonist, } \\
\text { lipopolysaccharide (LPS) injection, mesenchymal } \\
\text { stem/stromal cells therapy, statins, formononetin, } \\
\text { Serp-1 }\end{array}$ & {$[19,20,22,26]$} \\
\hline IL-16 & $\begin{array}{l}\text { Lymphocytes and microglia activation; } \\
\text { accumulation in cerebral vessels }\end{array}$ & anti-IL-16 antibody & [32] \\
\hline IL-17 & Neutrophils encroachment & Monoclonal antibodies & [33] \\
\hline IL-18 & Caspase- 1 activation & Exosomes, NLRP3 inhibitor & {$[18,29]$} \\
\hline IL-23 & $\begin{array}{l}\text { Leads to neurologic deficits } \\
\text { CHEMOKINES }\end{array}$ & Monoclonal antibodies & [33] \\
\hline CXCL1 & Neutrophil circulation into the brain & & \\
\hline CXCL3 & Migration of neutrophils across epithelial barriers & CXCL immunotherapy, glucagon-like peptide- 1 & \\
\hline $\begin{array}{l}\text { CXCL5 } \\
\text { CXCL } 8\end{array}$ & Microglia activation; BBB damage; astrogliosis & $\begin{array}{l}\text { receptor (GLP-1R) agonist } \\
\text { reptide-1 }\end{array}$ & {$[34,35]$} \\
\hline $\begin{array}{l}\text { CXLL8 } \\
\text { CXCL9 }\end{array}$ & $\begin{array}{l}\text { Neutrophil infiltration into brain parenchyma } \\
\text { Inhibition of selected T cells }\end{array}$ & & \\
\hline CXCL10 & $\begin{array}{l}\text { Blood-derived monocytes promotion (to } \\
\text { accumulate around perivascular vessels) }\end{array}$ & & \\
\hline
\end{tabular}

Under the pathological conditions of brain trauma, the number of neutrophils entering into the brain increases. Neutrophils are one of the earliest myeloid-derived cells that infiltrate the injured brain and affect secondary damage [36]. Neutrophils enroll to the injured site of the brain within $1 \mathrm{~h}$ of a focal injury, damage the parenchyma, and provoke secondary cellular injury and brain tissue damage [37,38].

The peak number of neutrophils that infiltrate the brain is observed $24 \mathrm{~h}$ after an injury, but cells infiltrate along the arterioles and venules within 5 min of closed brain damage [39,40]. The liver is the main center of the systemic response of neutrophils after brain damage. The production of host cytokines is a response to inflammation in a brain craving the maturation and granulation of neutrophils [41].The homeostatic feedback loop, the IL-23/IL-17/G-CSF axis that supervises neutrophil death and birth, is elevated after a brain injury [42].

Thus, what is the role of neutrophils in brain damage?

Free radicals induce disturbances of crucial transmembrane, tight-junction proteins such as occludin and claudin via the PI3K/AKT pathway, and finally, contribute to the break-up of BBB integrity and massive flux of molecules and cells across the barrier [43]. Neutrophil elastase is rapidly exhausted from activated neutrophils into the extracellular space, which intensifies the host inflammatory response. In addition, it can degrade the diversity of matrix and non-matrix proteins, such as proteins in plasma, proinflammatory mediators, or adhesion receptors $[44,45]$. These destructive effects of neutrophil elastase are observed though the early stage of a nervous system injury.

In addition, neutrophil-derived cytokines vary according to the underlying stimuli and tissues involved [46,47]. The specific variations of exterior phenotype, chemotaxis, and phagocytosis, which differ with classical inflammation, are observed according to a brain injury [48]. In neutrophils under brain injury status, in addition to normal proinflammatory 
cytokines, TNF, or chemokines CXCL-1, other anti-inflammatory cytokines or neutrotrophic factors can be found $[49,50]$.

Cerebral hypoperfusion intensifies the interactions of neutrophils with blood vessels. Previous studies have indicated that hypoperfusion advances neutrophils to collapse and attach by elevating the expression of L-selectin and intercellular adhesion molecule 1 (ICAM-1) in vascular endothelial cells [51]. Activated neutrophils organize pseudopods and attach to the endothelium and other structures such as platelets, finally inhibiting blood flow through the microvascular system and elevating the risk of ischemia and early coagulopathy [52-54] (Figure 2).

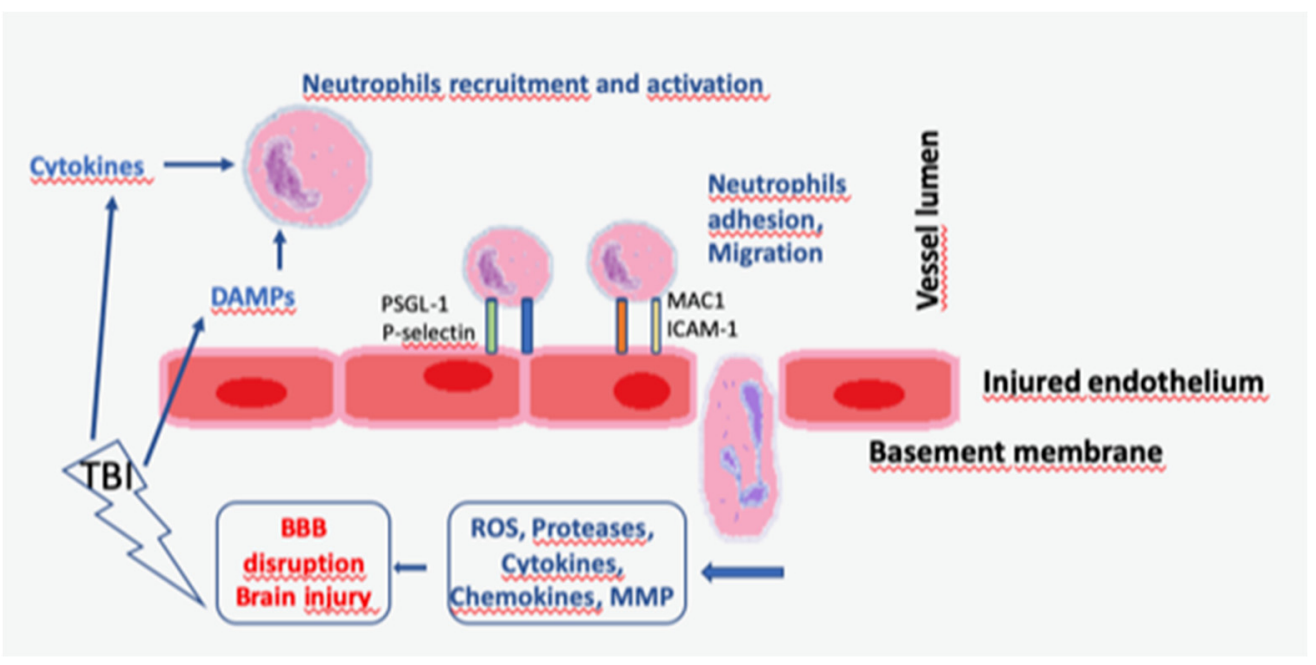

Figure 2. Neutrophil activation and circulation in TBI. After a TBI occurs, cells apoptosis and DAMPs leak into the extracellular spaces and activate immune cells. Activated neutrophils migrate towards the site of the injury. The elevated expression of adhesion molecules in endothelial cells, such as ICAM-1 or VCAM-1 1, increase the attachment and extravasation of peripheral immune cells into the central nervous system. Neutrophils (but also T cells and monocytes) penetrate the BBB. Neutrophils release toxic molecules including reactive oxygen species (ROS), nitrous oxide (NOS), NADPH oxidase, proinflammatory cytokines, and proteases, which advance secondary damage: DAMPs—danger/damage associated molecular patterns; ICAM-intercellular adhesion aolecule; MAC - membrane attack complex; MMP—-matrix metalloproteinase; PSGL-P-selectin glycoprotein ligand; TBI—traumatic brain injury.

In addition, vascular failure after neutrophils rolling is observed during and 4-8 h after injury [55]. Recent studies documented the important connection between neutrophils and hemorrhagic areas. Elevated activation of MMP-9 with basal lamina collagen IV mortification strongly amplifies the dysfunction of vessel integrity and development of hemorrhagic lesions [56]. Significantly, the aforementioned cells may induce iNOS $24-48 \mathrm{~h}$ after damage, which corresponds with hemorrhage and the dilution of vessels. One of the important questions is about the role of neutrophils in the conversion of hyperperfusion and hypoperfusion in the early stages after brain damage $[57,58]$.

Another important aspect of neutrophil function after brain injury is infiltration of choroid plexus and CSF circulation of these cells, close to sites of damage. The BBB breakdown predisposes the stronger activation of neutrophil migration to the central nervous system [59]. The selectins act as rolling cells and connect with ICAM-1, which is expressed in peripherial vessels and platelet-endothelial adhesion molecules (PECAM-1) expressed in the chyroid plexus, and modulate the migration of neutrophils. The potential inhibition of ICAM-1 and PECAM-1 may improve neuroinflammation treatment. In addition, CXCR2 ligand expression increases the forcing of the aforementioned cells to parenchyma [60]. 
The above-mentioned formation of NETs intensifies neurological damage after a brain injury. A recent experimental study showed that NET formation was associated with hypoperfusion and tissue hypoxia and a decreased level of circulating NETs correlated with elevated serum deoxyribonuclease 1 (DNase-I) activity in brain injury. Furthermore, TLR4 and kinase peptidylarginine deiminase 4 (PAD4) moderates NET formation and cerebral microvascular dysregulation $[15,48]$.

Neutrophils also damage the tight junction and permeability of BBB. The neutrophilreleased NE breakdown the cadherin-cadherin binding and are finally predisposed to BBB hyperpermeability as well as neutrophil-derived MMPs, such as MMP2, MMP3, MMP9, which dysregulate the blood-brain barrier after central nervous system injury [61,62].

As mentioned above, BBB breakdown connects neutrophils with the pathophysiology of edema. Recent data showed that inhibition of $\mathrm{Na}^{+} / \mathrm{H}^{+}$pump potentially decreases the cerebral infarct volume and neutrophil accumulation [63].

In summary, neutrophils are mediators during the early phase of secondary damage, exacerbate BBB damage, and promote the death of neuronal cells. Importantly, neutrophils are also determinants of long-term neurological recovery. A recent experimental study showed that the anti-CD11d treatment decreased macrophage and neutrophil activation and significantly improved outcomes focused on cognition, sensorimotor ability, and anxiety [64].

Mukherjee et al., in a large prospective study of isolated pediatric TBI patients, determined that a white cell count $>16.1 \times 109 / \mathrm{L}$ and a neutrophil count $>11.9 \times 109 / \mathrm{L}$ have predictive value for hospital length of stay and poor Pediatric Cerebral Performance Category Scale scores [65]. It is also worthwhile mentioning that a recent study by Dolmans et al., that demonstrated routine blood tests such as WBC and neutrophil count measured after severe TBI, upon admission, were not predictive of 30-day mortality, hospital length of stay, or outcome after 3 months [66].

\section{Lymphocytes in Brain Injury}

Peripheral immune system suppression is a predisposition for lymphopenia, which takes place in almost $80 \%$ of TBI patients [67]. Petrone et al., reported different lymphocyte dynamics in mild and severe TBI patients in the first $48 \mathrm{~h}$ after TBI. The elevation of lymphocyte count was significantly more dynamic in mild TBI especially after $48 \mathrm{~h}$ [68].

The effect and role of $\mathrm{T}$ lymphocytes in brain injured patients still remains to be investigated. A recent study showed that mainly adaptive immune response $\mathrm{T}$ cells infiltrate the site of a lesion. This process is increased by ROS released from neutrophils and occurs simultaneously with monocyte and macrophages [69].

Experimental studies on TBI and blood and brain tissues have reported the proliferation of naïve $\mathrm{T}$ lymphocytes, the polarization of effector $\mathrm{T}$ lymphocytes, and finally, suppression of the production of regulatory cells [52]. Peripheral M1 macrophages migrate towards the central nervous system and activate $\mathrm{T}$ cell proliferation and evolution to TH1 and TH17 proinflammatory subtypes. The $\gamma \delta \mathrm{T}$ and Th17 cells activate a proinflammatory microglia via modulating the FasL/PTPN2/TNF- $\alpha$ pathway. These mechanisms aggravate ischemic brain injury [70]. A concomitant reduction in Foxp3 + TREG production and elevation of the TH17/TREG ratio for weeks after a TBI are indicators of long-term adaptive immune responses. In addition, some studies have documented that T lymphocytes may not represent an important place in the pathogenesis of primary destruction in the brain during the first seven days after an injury [51].

A murine model has shown that consumption of regulatory $\mathrm{T}$ cells impairs $\mathrm{T}$ cell infiltration into the central nervous system, elevates reactive astrogliosis, and interferon- $\gamma$ gene expression [46]. In addition, these autoreactive T lymphocytes probably induce the process of healing in an injured brain $[52,54]$.

Recent evidence suggests that lymphocytes present particular relevance for lesion development. The data from an animal study indicated that lymphocyte-deficient RAG1 mice were secured from cortex stab wound damage [71]. The T lymphocyte CD4+ inhibitory 
agents significantly decreased acute damage of an injured brain in mice. Lymphocyte CD4+ participates in apoptosis activation in brain cells by cytokine production as TNF alpha or by FAS dependent pathways [72]. Prolonged immune system activation in the brain generates neurodegeneration and, finally, causes neurological disturbances [53]. The prevention of $\mathrm{T}$ cell migration to the central nervous system probably decreases neurodegeneration [73]. The elevation of effector/memory CD8+ T cells, which precedes interleukin-17/CD4+ T cell infiltration, has been connected with escalating neurological and motor impairment, increased of circulating brain-specific autoantibodies, and myelin pathology. An inadequacy or decrease in CD8+ T cells improved outcomes [70].

In addition, the CD3+/CD4-/CD8- T cells (double-negative T cells), known as $\gamma \delta$ $\mathrm{T}$ cells, regulate the immune system and inflammatory homeostasis, and the number of these cells is significantly increased in a time-dependent manner in the central nervous system and peripheral blood [74,75]. However, Th17 cells present a crucial role in the secondary injury in the chronic phase after ischemic stroke. Furthermore, these cells are observed 1 week after traumatic brain injury (TBI) and intensified the cytotoxicity of CD8+ $\mathrm{T}$ cells at a next stage; therefore, the CD8+ T cell detrimental effect was observed [70,76]. Recent studies have documented that a stimulated level of IL-17 in peripheral blood samples is associated with worse final neurological outcomes. An elevated level of IL-17 has been observed in the peripheral blood 3 days after stroke [77,78]. It remains to be explained which types of immune system cells are responsible and crucial for stimulation of IL-17 [79,80]. In addition, a reduction in peripheral lymphocyte activation inhibited neurodegeneration and a decrease in lesion size was observed after a TBI [81].

The above-mentioned studies, indicate the need for novel methods of treatment after trauma, including influencing the cells of the immune system. A recent study by Nowell et al., showed that antagonizing of macrophage migration inhibitory factor (MIF) presented anti-neuroinflammatory and neuroprotective effects [82]. The results showed that administration of the MIF antagonist, as early as 30 min after an injury, prevented astrogliosis and growth of $\gamma \delta \mathrm{T}$ cells in the gut, inhibited the percentage of B cells infiltrating the brain, and finally predisposed the patient to a decrease in post-traumatic syndromes such as epilepsy.

\section{NLR in TBI}

The NLR is a rapid and simple parameter of inflammation. Several studies have reported that neutrophil count is usually elevated and lymphocytes presented no significant changes during the acute phase after a brain injury [2,3].

In addition, neutrophils are one of the fastest responders and mediators of secondary pathophysiology processes after TBI [83]. Lymphocytes are also very dynamic immune cells. Mrakovcic-Sutic et al., documented that the percentage of cytotoxic lymphocytes significantly decreased at day 1 and 4, and their number elevated at day 7 [84].

In recent years there has been a growing interest in NLR as a barometer of inflammation and a marker of secondary injury associated with cell activation and immune system response.

Brain trauma activates a cascade of various immune processes in the central nervous system. It is worth mentioning that the brain-multiorgan interactions seems to be important, because the brain is a central controller of the body. These interactions include relationships between brain and heart, lung, liver, kidneys and microbiome [85]. Brain damage increases the risk of complications from the above-mentioned organs and systems, increasing mortality in this group of patients. The immune system plays a critical role in this interaction as well as specific bidirectional immune system and brain axis [86]. Activation of neutrophils and lymphocytes in acute brain damage affects the imbalance in communication between the immune system and central nervous system [87] (Figure 3). 


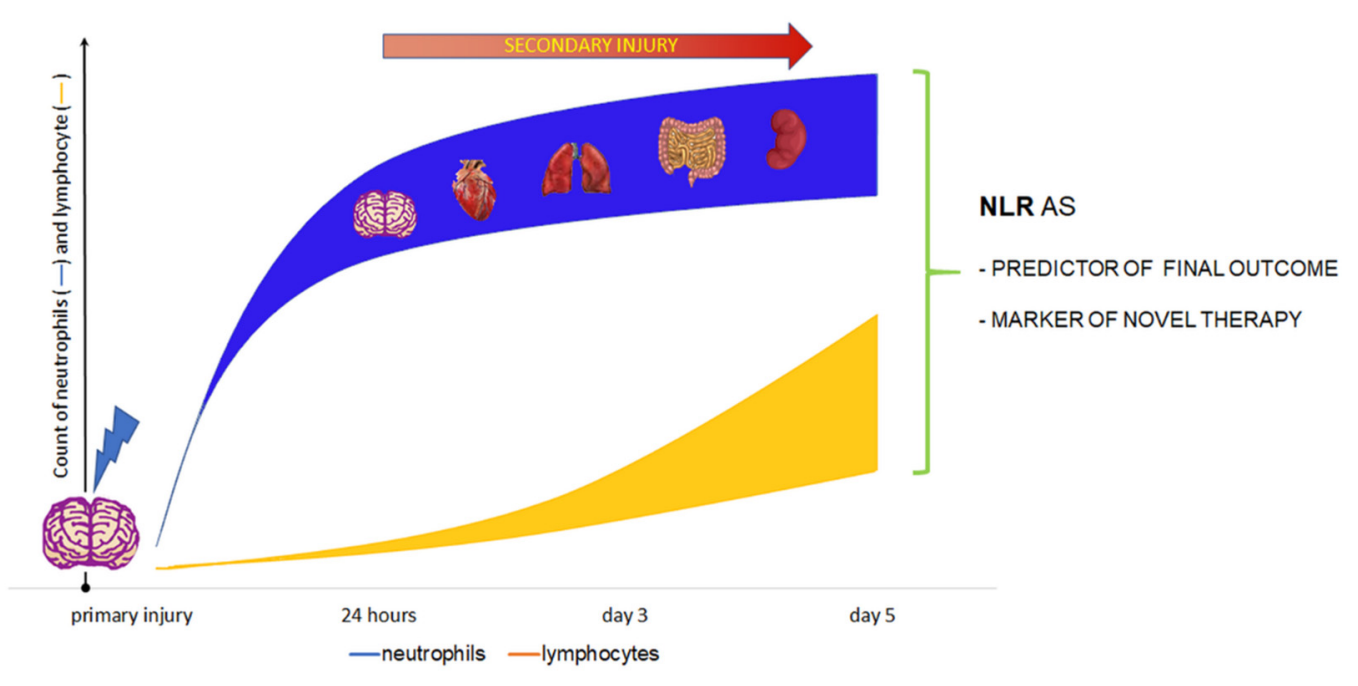

Figure 3. The place of the NLR in clinical management and final outcome prediction after acute brain injury. The peak number of neutrophils that infiltrate the brain is observed $24 \mathrm{~h}$ after an injury. The elevation of lymphocytes count is significantly more dynamic, especially after $48 \mathrm{~h}$.

\section{Prognostic Value of the NLR in TBI}

Several studies have reported that the NLR may be a low-cost, objective, and available predictor of outcome in certain groups of patients, for example, in sepsis, lung cancer, pancreatic cancer, pancreatitis, hepatocellular carcinoma, pulmonary embolism, or cardiovascular diseases. Huang et al., reported that NLR is a helpful prognostic biomarker in sepsis and elevation of this value predisposes the patient to an unfavorable outcome in this group of patients $[65,88]$. In addition, NLR may also become a powerful presage of the inflammatory status and prognosis conditions of patients with glial tumor, ischemic, and hemorrhagic stroke and status epilepticus [89-92].

The outcome for patients after a TBI correlates significantly with age, pupillary reaction, Glasgow Coma Score (GCS) at admission, type of damage, coagulopathy as INR, and APTT. Recent studies have shown close correlations between final outcomes and total white blood cells (WBC), count lymphocyte ratio, count neutrophil ratio, NLR, platelet count, or platelet-to-lymphocyte ratio. Several studies have presented that a NLR value at admission might effectively predict outcome and mortality after a severe brain injury. The NLR potentially outperformed the predictive value of $\mathrm{WBC}$, absolute neutrophil count (ANC), and absolute lymphocyte count, and is a reliable dynamic index of systemic inflammation that combines adaptive and innate immune system response pathways [59,74].

Importantly, the NLR may be a predictor of an hyper-acute inflammatory response as secondary damage and represents several advantages in the prediction of patients with severe brain injury.

\subsection{NLR and Mortality}

In a retrospective study, Chen et al., documented that the NLR amount on admission might be effective for predicting the one-year outcome and mortality in severe brain injury patients [93]. Similar conclusions by Huang et al. showed that a group of patients with a diagnosis of acute $\mathrm{SAH}$, where increased red blood cell distribution width (RDW) and NLR were connected with higher observed one-year mortality, had an adjusted hazard ratio 1.03 (95\% CI, 1.00-1.05) for per 1 increased NLR [94].

Significantly higher NLR in patients who died, shows that increased NLR, as well as age on admission, significantly predict the worse one-year outcome (age: $\mathrm{OR}=1.068$, 95\% CI 1.052-1.083 and NLR: OR $=1.100,95 \%$ CI 1.064-1.138, $p<0.9038$ ) [68].

An additional study documented that an NLR value on admission higher than 15.63 has been shown to be an effective indicator of 28-day mortality and was greatly higher in DAI (diffuse axonal injury) patients as compared with CE (hemispheric or focal cerebral 
edema), ICH (intracerebral hemorrhage), and S-EH/SAH (epidural and/or subdural hematoma/subarachnoid hemorrhage) groups [95]. Another multivariate analysis revealed that NLR at admission was an independent prognostic factor of six-month outcome in a group after severe brain trauma (OR 0.91, 95\% CI 0.89-0.93, $p<0.001$ ) [96].

\subsection{NLR and Clinical Outcome}

Kimball et al. observed, in general, that higher NLR values $24 \mathrm{~h}$ and $48 \mathrm{~h}$ after TBI in pediatric patients were associated with worse final outcomes [97]. Recent results showed a higher NLR association with the Glasgow Outcome Score (GOS) or Glasgow Outcome Scale Extended (GOSE) [95-97]. Giede-Jeppe et al., described that NLR $\geq 7.05$ is a good cut-off value to predict an unfavorable outcome, which indicates an $\mathrm{mRS}$ score of 3-6 after 3 months [98]. Further analyses performed by Wang et al., also found the positive correlation between the NLR and the Hunt-Hess grade. Authors showed that NLR may predict the adverse final outcome of patients with an mRS score of 3-5 after 3 months [99].

An elevated NLR is also an independent predictor for complications in patients with acute ischemic stroke (AIS), such as cerebral edema hemorrhagic transformation and ICH after endovascular treatment [100-102].

Additionally, its high value could predict functional independence, death, and risk of post-ischemic intracranial hemorrhage independent of age, treatment, and degree of recanalization $[103,104]$.

The previously mentioned study by Mukherjee et al., also reported that an NLR above 5.2 predisposed a patient to a longer length of hospitalization and that Pediatric Cerebral Performance Category Scale (PCPCS) scores were less favorable. In addition, the NLR was after the GCS value as the next important independent risk marker for a worse outcome [65].

In recent years, one of the scientific questions has been, "Are NLR changes more objective than GCS changes?" Generally, the conditions reflected by the NLR and, importantly, the GCS assessment, are sedated, ventilated patients with severe periorbital swelling.

The power of the NLR for predicting the functional outcome of a brain injury may be very useful in relation to an outcome predicted by the Glasgow Coma Scale. Several studies have documented that higher NLR values are associated with lower GCS scores. Chen et al., summarized that the performance of the NLR for predicting a functional outcome in severe TBI was similar to GCS scores (AUC $=0.719,95 \%$ CI 0.673-0.766). Nonetheless, some studies have highlighted that NLR is a weaker predictor of mortality in TBI patients than GCS $[73,93,105]$.

Furthermore, other studies have noted that the impact of NLR on functional outcome should be analyzed in relation to pre-existing comorbidities versus whether it represents an independent causal relationship in the context of the observed immunosuppression [76]. In addition, Aexiou et al. investigated the role of NLR on the admission of brain-injured patients for predicting the need for CT scans in mild TBI. This study reported that higher NLR levels correspond with positive CT findings in mild TBI and suggested that a cut-off value of 2.5 could be used to quickly detect the need for a CT scan in mild brain injury with $78.1 \%$ sensitivity and $63 \%$ specificity [106].

\subsection{NLR as Not Good Predictor of Mortality and Morbidity}

However, in opposition to the above-mentioned studies, another recent study has documented that, in addition to the IMPACT and CRASH prognostic models, the NLR value at admission was not a good predictor of mortality and morbidity in moderate and severe TBI (AUC 0.58 and AUC 0.47) [107]. In addition, Corbett et al. reported that the NLR value was not significantly correlated with a risk of unfavorable outcome (AUROC, $0.500, p=0.998)$ [108]. 


\section{Neutrophils as a Target of Future Therapies}

Neutrophils play an important role in many diseases such as pulmonary, cardiovascular autoimmune, infectious diseases, sepsis, and, the subject of this review, neuroinflammation and neurodegenerative diseases. Several studies are aiming to control neutrophils, their production, accumulation, or crucial changes in phenotype as a novel target therapy. For example, the CXCR2 antagonists' effect is documented in a group of patients with asthma [109]. Other products, such as neutrophil elastase inhibitor, present positive properties in bronchiolitis obliterans [110]. The NETs effect is another promising future strategy. A crucial enzyme for intravascular and intraparenchymal neutrophil extracellular traps (NETs) formation-peptidylarginine deiminase 4 (PAD4)—is strongly activated in ischemic brain and overexpression predisposition to NET production and finally to decreased neovascularization and BBB disruption. Potentially, NET formation blockade by a PAD inhibitor may improve recovery [111].

Thus, therapeutic methods targeting neutrophils can involve many strategies such as increasing circulating neutrophil number (manipulation of the CXCL-12-CXCR-4 pathway), expressing their inhibitory receptors, targeting neutrophil production and activation by G-CSF, promoting neutrophil apoptosis, blocking chemokine functions, blocking neutrophils delivered mediators, or using selectin or integrin blockers [112-117]. As shown in Table 1 neutrophils may become a target in therapy after brain injury. Recent data showed that targeting DNA sensor cyclic GMP-AMP synthase (cGAS) or NETs potentially benefitted thrombolytic therapy in patients with ischemic stroke by decreasing tPA-associated hemorrhage [118].

\section{NLR-A Potential Marker of Future Therapies in Chronic Neuroinflammation}

Primary brain injuries impact crucial cellular processes causing secondary cell death mechanisms such as mitochondrial dysfunction, oxidative stress, BBB disruption, and chronic inflammatory processes. Chronic traumatic brain injury, similarly to acute TBI, includes neuroinflammation and, finally, contributes to long-term disabilities. In addition, in primary brain damage, neuroinflammation is helpful by stimulating an anti-inflammatory response. Sequentially, in the chronic brain injury stage an uncontrolled inflammation stimulates the pathological symptoms and follows the initial damage even 17 years after TBI [119]. Chronic neuroinflammation is connected with endogenous repair mechanisms and immune cells, microglia, cytokines, and chemokines. This inflammatory cells, neutrophils, monocytes, and lymphocytes cross the BBB and release prostaglandins and proinflammatory cytokines. Inflammatory regulators recruit microglia and immune cells to the brain by activating the expression of chemokines and cell adhesion molecules. Thus, NLR may be a useful, low cost marker, showing the peripheral inflammation and its correspondance with neurodegeneration [120-123]. In addition, chronic neuroinflammation may become a potential target for novel therapy as a select method of conversion from proinflammatory to anti-inflammatory reactions. Several studies focus on methods to intensify the protective effects of inflammation. Recent publications show positive effects of several drugs such as minocycline, melatonin, statins, subdural infusion of serpine- 1 , mesenchymal stem cells therapy [124-129]. All of these therapies can modulate a neuroinflammatory response, which may affect NLR.

Although several studies have described the credibility of NRL in the prognosis of the outcome and efficacy of revascularization in ischemic stroke patients, its usefulness in assessing treatment efficacy has been poorly recognized in patients with TBI. A lot of studies have documented its predicting value in response to treatment in cancer and immunomodulation therapies [130-132]. Gudson et al., showed a strong correlation between baseline NLR and 24-h growth of perihematomal edema in patients treated for intracranial hemorrhage, however they analyzed only a relationship between the expansion of cerebral edema and NLR [133]. Changes in NLR in TBI patients were analyzed by Petrone et al. [68]. Severe TBI caused an increase in NLR above 5.0 at $48 \mathrm{~h}$ of treatment, whereas its values decreased following treatment in patients treated for mild TBI. Based on their results it 
can be speculated that an increase in NLR results from a neuroinflammatory response to trauma and a non- or poor response to treatment, however they did not analyze the changes in NLR as the efficacy response to treatment. It is worth stressing that the analysis of changes in NLR as a response to treatment seems be very useful in TBI patients as it can modulate a treatment before critical events.

Regulation of the activation and deactivation of immune cells and the above-mentioned processes may be important in the brain's recovery. Potential strategies in sequestering inflammation and its associated neurodegenerative processes need future study.

\section{Conclusions}

The NLR is a simple and low-cost index of systemic inflammation status and has been shown to have prognostic value for predicting poorer functional outcomes and elevated mortality rates in TBI patients. However, the NLR differentiation of TBI types needs further study.

Author Contributions: Conceptualization, D.S.-G. and W.D.; writing—original draft preparation, D.S.-G. and W.D.; writing—review and editing D.S.-G. and W.D.; visualization, D.S.-G. and W.D. All authors have read and agreed to the published version of the manuscript.

Funding: This research received no external funding.

Institutional Review Board Statement: Not applicable.

Informed Consent Statement: Not applicable.

Conflicts of Interest: The authors declare no conflict of interest.

\section{References}

1. Balu, R. Inflammation and Immune System Activation After Traumatic Brain Injury. Curr. Neurol. Neurosci. Rep. 2014, 14, 484. [CrossRef] [PubMed]

2. Helmy, A.; De Simoni, M.G.; Guilfoyle, M.R.; Carpenter, K.L.H.; Hutchinson, P.J. Cytokines and innate inflammation in the patho-genesis of human traumatic brain injury. Prog. Neurobiol. 2011, 95, 352-372. [CrossRef] [PubMed]

3. Kolaczkowska, E.; Kubes, P. Neutrophil recruitment and function in health and inflammation. Nat. Rev. Immunol. 2013, 13, 159-175. [CrossRef] [PubMed]

4. Capizzi, A.; Woo, J.; Verduzco-Gutierrez, M. Traumatic Brain Injury: An Overview of Epidemiology, Pathophysiology, and Medical Management. Med. Clin. N. Am. 2020, 104, 213-238. [CrossRef] [PubMed]

5. Hawkins, B.; Davis, T. The Blood-Brain Barrier/Neurovascular Unit in Health and Disease. Pharmacol. Rev. 2005, 57, 173-185. [CrossRef] [PubMed]

6. Mrass, P.; Weninger, W. Immune cell migration as a means to control immune privilege: Lessons from the CNS and tumors. Immunol. Rev. 2006, 213, 195-212. [CrossRef] [PubMed]

7. Ge, S.; Song, L.; Serwanski, D.R.; Kuziel, W.A.; Pachter, J.S. Transcellular transport of CCL2 across brain microvascular endothelial cells. J. Neurochem. 2008, 104, 1219-1232. [CrossRef] [PubMed]

8. Pillay, J.; Braber, I.D.; Vrisekoop, N.; Kwast, L.M.; De Boer, R.; Borghans, J.A.M.; Tesselaar, K.; Koenderman, L. In vivo labeling with $2 \mathrm{H} 2 \mathrm{O}$ reveals a human neutrophil lifespan of 5.4 days. Blood 2010, 116, 625-627. [CrossRef]

9. Adrover, J.M.; Ávila, J.; Ángel, N.; Hidalgo, A. Aging: A Temporal Dimension for Neutrophils. Trends Immunol. 2016, 37, 334-345. [CrossRef] [PubMed]

10. Casanova-Acebes, M.; Pitaval, C.; Weiss, L.A.; Nombela-Arrieta, C.; Chèvre, R.; Gonzalez, N.A.; Kunisaki, Y.; Zhang, D.; van Rooijen, N.; Silberstein, L.E.; et al. Rhythmic Modulation of the Hematopoietic Niche through Neutrophil Clearance. Cell 2013, 153, 1025-1035. [CrossRef] [PubMed]

11. Zhang, D.; Chen, G.; Manwani, D.; Mortha, A.; Xu, C.; Faith, J.J.; Burk, R.D.; Kunisaki, Y.; Jang, J.-E.; Scheiermann, C.; et al. Neutrophil ageing is regulated by the microbiome. Nat. Cell Biol. 2015, 525, 528-532. [CrossRef]

12. Hoenderdos, K.; Lodge, K.M.; Hirst, R.A.; Chen, C.; Palazzo, S.G.C.; Emerenciana, A.; Summers, C.; Angyal, A.; Porter, L.; Juss, J.K.; et al. Hypoxia upregulates neutrophil degranulation and potential for tissue injury. Thorax 2016, 71, 1030-1038. [CrossRef] [PubMed]

13. Kjeldsen, L.; Cowland, J.B.; Johnsen, A.H.; Borregaard, N. SGP28, a novel matrix glycoprotein in specific granules of human neutrophils with similarity to a human testis-specific gene product and to a rodent sperm-coating glycoprotein. FEBS Lett. 1996, 380, 246-250. [CrossRef]

14. Klopf, J.; Brostjan, C.; Neumayer, C.; Eilenberg, W. Neutrophils as Regulators and Biomarkers of Cardiovascular Inflammation in the Context of Abdominal Aortic Aneurysms. Biomedicines 2021, 9, 1236. [CrossRef] [PubMed] 
15. Vaibhav, K.; Braun, M.; Alverson, K.; Khodadadi, H.; Kutiyanawalla, A.; Ward, A.; Banerjee, C.; Sparks, T.; Malik, A.; Rashid, M.H.; et al. Neutrophil extracellular traps exacerbate neurological deficits after traumatic brain injury. Sci. Adv. 2020, 6, eaax8847. [CrossRef] [PubMed]

16. Zhu, K.; Zhu, Y.; Hou, X.; Chen, W.; Qu, X.; Zhang, Y.; Li, Z.; Wang, C.; Chen, J.; Lv, L.; et al. NETs Lead to Sympathetic Hyperactivity After Traumatic Brain Injury Through the LL37-Hippo/MST1 Pathway. Front. Neurosci. 2021, 15. [CrossRef]

17. Fortin, C.F.; Ear, T.; McDonald, P.P. Autocrine role of endogenous interleukin-18 on inflammatory cytokine generation by human neutrophils. FASEB J. 2009, 23, 194-203. [CrossRef] [PubMed]

18. Kuwar, R.; Rolfe, A.; Di, L.; Xu, H.; He, L.; Jiang, Y.; Zhang, S.; Sun, D. A novel small molecular NLRP3 inflammasome inhibitor alleviates neuroinflammatory response following traumatic brain injury. J. Neuroinflamm. 2019, 16, 81. [CrossRef]

19. Battaglini, D.; Siwicka-Gieroba, D.; Rocco, P.R.; Cruz, F.F.; Silva, P.L.; Dabrowski, W.; Brunetti, I.; Patroniti, N.; Pelosi, P.; Robba, C. Novel Synthetic and Natural Therapies for Traumatic Brain Injury. Curr. Neuropharmacol. 2021, 19, 1661-1687. [CrossRef]

20. Dabrowski, W.; Siwicka-Gieroba, D.; Kotfis, K.; Zaid, S.; Terpilowska, S.; Robba, C.; Siwicki, A.K. The Brain-gut Axis-where are we now and how can we Modulate these Connections? Curr. Neuropharmacol. 2021, 19, 1164-1177. [CrossRef]

21. Ren, H.; Kong, Y.; Liu, Z.; Zang, D.; Yang, X.; Wood, K.; Li, M.; Liu, Q. Selective NLRP3 (Pyrin Domain-Containing Protein 3)Inflammasome Inhibitor Reduces Brain Injury After Intracerebral Hemorrhage. Stroke 2018, 49, 184-192. [CrossRef]

22. Wang, J.; Jiang, C.; Zhang, K.; Lan, X.; Chen, X.; Zang, W.; Wang, Z.; Guan, F.; Zhu, C.; Yang, X.; et al. Melatonin receptor activation provides cerebral protection after traumatic brain injury by mitigating oxidative stress and inflammation via the Nrf2 signaling pathway. Free Radic. Biol. Med. 2019, 131, 345-355. [CrossRef] [PubMed]

23. Zheng, J.; Dai, Q.; Han, K.; Hong, W.; Jia, D.; Mo, Y.; Lv, Y.; Tang, H.; Fu, H.; Geng, W. JNK-IN-8, a c-Jun N-terminal kinase inhibitor, improves functional recovery through suppressing neuroinflammation in ischemic stroke. J. Cell. Physiol. 2020, 235, 2792-2799. [CrossRef] [PubMed]

24. Mairesse, J.; Zinni, M.; Pansiot, J.; Hassan-Abdi, R.; Demene, C.; Colella, M.; Charriaut-Marlangue, C.; Novais, A.R.B.; Tanter, M.; Maccari, S.; et al. Oxytocin receptor agonist reduces perinatal brain damage by targeting microglia. Glia 2018, 67, 345-359. [CrossRef] [PubMed]

25. Zhang, H.-B.; Tu, X.-K.; Song, S.-W.; Liang, R.-S.; Shi, S.-S. Baicalin Reduces Early Brain Injury after Subarachnoid Hemorrhage in Rats. Chin. J. Integr. Med. 2020, 26, 510-518. [CrossRef]

26. Nishihara, T.; Ochi, M.; Sugimoto, K.; Takahashi, H.; Yano, H.; Kumon, Y.; Ohnishi, T.; Tanaka, J. Subcutaneous injection containing IL-3 and GM-CSF ameliorates stab wound-induced brain injury in rats. Exp. Neurol. 2011, 229, 507-516. [CrossRef] [PubMed]

27. Taylor, R.A.; Chang, C.F.; Goods, B.A.; Hammond, M.D.; Mac Grory, B.; Ai, Y.; Steinschneider, A.F.; Renfroe, S.C.; Askenase, M.H.; McCullough, L.D.; et al. TGF- $\beta 1$ modulates microglial phenotype and promotes recovery after intracerebral hemorrhage. J. Clin. Investig. 2017, 127, 280-292. [CrossRef]

28. Sharma, S.; Kumar, A.; Choudhary, A.; Sharma, S.; Khurana, L.; Sharma, N.; Kumar, V.; Bisht, A. Neuroprotective Role of Oral Vitamin D Supplementation on Consciousness and Inflammatory Biomarkers in Determining Severity Outcome in Acute Traumatic Brain Injury Patients: A Double-Blind Randomized Clinical Trial. Clin. Drug Investig. 2020, 40, 327-334. [CrossRef] [PubMed]

29. Williams, A.M.; Wu, Z.; Bhatti, U.F.; Biesterveld, B.E.; Kemp, M.T.; Wakam, G.K.; Vercruysse, C.A.; Chtraklin, K.; Siddiqui, A.Z.; Pickell, Z.; et al. Early single-dose exosome treatment improves neurologic outcomes in a 7-day swine model of traumatic brain injury and hemorrhagic shock. J. Trauma Acute Care Surg. 2020, 89, 388-396. [CrossRef] [PubMed]

30. Szot, P.; Franklin, A.; Figlewicz, D.P.; Beuca, T.P.; Bullock, K.; Hansen, K.; Banks, W.A.; Raskind, M.A.; Peskind, E.R. Multiple lipopolysaccharide (LPS) injections alter interleukin 6 (IL-6), IL-7, IL-10 and IL-6 and IL-7 receptor mRNA in CNS and spleen Neuroscience 2017, 355, 9-21. [CrossRef] [PubMed]

31. Tan, S.; Shan, Y.; Wang, Y.; Lin, Y.; Liao, S.; Deng, Z.; Zhou, L.; Cai, W.; Zeng, Q.; Zhang, L.; et al. Exacerbation of oxygen-glucose deprivation-induced blood-brain barrier disruption: Potential pathogenic role of interleukin-9 in ischemic stroke. Clin. Sci. 2017, 131, 1499-1513. [CrossRef]

32. Skundric, D.S.; Dai, R.; Zakarian, V.L.; Bessert, D.; Skoff, R.P.; Cruikshank, W.W.; Kurjakovic, Z. Anti-IL-16 therapy reduces CD4+ T-cell infiltration and improves paralysis and histopathology of relapsing EAE. J. Neurosci. Res. 2005, 79, 680-693. [CrossRef] [PubMed]

33. Sieper, J.; Poddubnyy, D.; Miossec, P. The IL-23-IL-17 pathway as a therapeutic target in axial spondyloarthritis. Nat. Rev. Rheumatol. 2019, 15, 747-757. [CrossRef]

34. Bagheri, H.; Pourhanifeh, M.H.; Derakhshan, M.; Mahjoubin-Tehran, M.; Ghasemi, F.; Mousavi, S.; Rafiei, R.; AbbaszadehGoudarzi, K.; Mirzaei, H.R.; Mirzaei, H. CXCL-10: A new candidate for melanoma therapy? Cell. Oncol. 2020, 43, 353-365. [CrossRef]

35. Shan, Y.; Tan, S.; Lin, Y.; Liao, S.; Zhang, B.; Chen, X.; Wang, J.; Deng, Z.; Zeng, Q.; Zhang, L.; et al. The glucagon-like peptide-1 receptor agonist reduces inflammation and blood-brain barrier breakdown in an astrocyte-dependent manner in experimental stroke. J. Neuroinflamm. 2019, 16, 242. [CrossRef] [PubMed]

36. Semple, B.D.; Trivedi, A.; Gimlin, K.; Noble-Haeusslein, L.J. Neutrophil elastase mediates acute pathogenesis and is a determinant of long-term behavioral recovery after traumatic injury to the immature brain. Neurobiol. Dis. 2015, 74, 263-280. [CrossRef] [PubMed] 
37. Kenne, E.; Erlandsson, A.; Lindbom, L.; Hillered, L.; Clausen, F. Neutrophil depletion reduces edema formation and tissue loss following traumatic brain injury in mice. J. Neuroinflamm. 2012, 9, 17. [CrossRef] [PubMed]

38. Nguyen, H.X.; O’Barr, T.J.; Anderson, A.J. Polymorphonuclear leukocytes promote neurotoxicity through release of matrix metalloproteinases, reactive oxygen species, and TNF- $\alpha$. J. Neurochem. 2007, 102, 900-912. [CrossRef] [PubMed]

39. Hallenbeck, J.M.; Dutka, A.J.; Tanishima, T.; Kochanek, P.M.; Kumaroo, K.K.; Thompson, C.B.; Obrenovitch, T.P.; Contreras, T.J. Polymorphonuclear leukocyte accumulation in brain regions with low blood flow during the early postischemic period. Stroke 1986, 17, 246-253. [CrossRef] [PubMed]

40. Kochanek, P.M.; Wallisch, J.S.; Bayır, H.; Clark, R.S.B. Pre-clinical models in pediatric traumatic brain injury-challenges and lessons learned. Child's Nerv. Syst. 2017, 33, 1693-1701. [CrossRef]

41. Furze, R.C.; Rankin, S.M. Neutrophil mobilization and clearance in the bone marrow. Immunology 2008, 125, 281-288. [CrossRef] [PubMed]

42. Banks, W.A.; Dohi, K.; Hansen, K.; Thompson, H.J. Assessing blood granulocyte colony-stimulating factor as a potential bi-omarker of acute traumatic brain injury in mice and humans. Brain Behav. Immun. 2016, 52, 81-87. [CrossRef]

43. Wang, Z.-G.; Cheng, Y.; Yu, X.-C.; Ye, L.-B.; Xia, Q.-H.; Johnson, N.R.; Wei, X.; Chen, D.-Q.; Cao, G.; Fu, X.-B.; et al. bFGF Protects Against Blood-Brain Barrier Damage Through Junction Protein Regulation via PI3K-Akt-Rac1 Pathway Following Traumatic Brain Injury. Mol. Neurobiol. 2016, 53, 7298-7311. [CrossRef] [PubMed]

44. Owen, C.A.; Campbell, E.J. The cell biology of leukocyte-mediated proteolysis. J. Leukoc. Biol. 1999, 65, 137-150. [CrossRef] [PubMed]

45. Lee, W.L.; Downey, G.P. Leukocyte elastase: Physiological functions and role in acute lung injury. Am. J. Respir. Crit. Care Med. 2001, 164, 896-904. [CrossRef] [PubMed]

46. Teng, T.-S.; Ji, A.-L.; Ji, X.-Y.; Li, Y.-Z. Neutrophils and Immunity: From Bactericidal Action to Being Conquered. J. Immunol. Res. 2017, 2017, 9671604. [CrossRef] [PubMed]

47. Mantovani, A.; Cassatella, M.A.; Costantini, C.; Jaillon, S. Neutrophils in the activation and regulation of innate and adaptive immunity. Nat. Rev. Immunol. 2011, 11, 519-531. [CrossRef]

48. Keeling, K.L.; Hicks, R.R.; Mahesh, J.; Billings, B.B.; Kotwal, G.J. Local neutrophil influx following lateral fluid-percussion brain injury in rats is associated with accumulation of complement activation fragments of the third component (C3) of the com-plement system. J. Neuroimmunol. 2000, 105, 20-30. [CrossRef]

49. Johnson, E.A.; Dao, T.L.; Guignet, M.; Geddes, C.E.; Koemeter-Cox, A.I.; Kan, R.K. Increased expression of the chemokines CXCL1 and MIP- $1 \alpha$ by resident brain cells precedes neutrophil infiltration in the brain following prolonged soman-induced status epilepticus in rats. J. Neuroinflamm. 2011, 8, 41. [CrossRef] [PubMed]

50. Csuka, E.; Morganti-Kossmann, M.C.; Lenzlinger, P.M.; Joller, H.; Trentz, O.; Kossmann, T. IL-10 levels in cerebrospinal fluid and serum of patients with severe traumatic brain injury: Relationship to IL-6, TNF-alpha, TGF-beta1 and blood-brain barrier function. J. Neuroimmunol. 1999, 101, 211-221. [CrossRef]

51. Yang, L.; Froio, R.M.; Sciuto, T.E.; Dvorak, A.M.; Alon, R.; Luscinskas, F.W. ICAM-1 regulates neutrophil adhesion and transcellular migration of TNF- $\alpha$-activated vascular endothelium under flow. Blood 2005, 106, 584-592. [CrossRef]

52. Emerich, D.F.; Dean, R.L.; Bartus, R.T. The Role of Leukocytes Following Cerebral Ischemia: Pathogenic Variable or Bystander Reaction to Emerging Infarct? Exp. Neurol. 2002, 173, 168-181. [CrossRef] [PubMed]

53. Zhang, X.; Cheng, R.; Rowe, D.; Sethu, P.; Daugherty, A.; Yu, G.; Shin, H.Y. Shear-Sensitive Regulation of Neutrophil Flow Behavior and Its Potential Impact on Microvascular Blood Flow Dysregulation in Hypercholesterolemia. Arter. Thromb. Vasc. Biol. 2014, 34, 587-593. [CrossRef] [PubMed]

54. Cohen, M.J.; Brohi, K.; Ganter, M.T.; Manley, G.T.; Mackersie, R.C.; Pittet, J.-F. Early Coagulopathy After Traumatic Brain Injury: The Role of Hypoperfusion and the Protein C Pathway. J. Trauma Inj. Infect. Crit. Care 2007, 63, 1254-1262. [CrossRef] [PubMed]

55. Palmer, C.; Roberts, R.L.; Young, P.I. Timing of neutrophil depletion influences long-term neuroprotection in neonatal rat hy-poxic-ischemic brain injury. Pediatr Res. 2004, 55, 549-556. [CrossRef]

56. Rosell, A.; Cuadrado, E.; Ortega-Aznar, A.; Hernandez-Guillamon, M.; Lo, E.H.; Montaner, J. MMP-9-positive neutrophil infil-tration is associated to blood-brain barrier breakdown and basal lamina type IV collagen degradation during hemorrhagic transformation after human ischemic stroke. Stroke 2008, 39, 1121-1126. [CrossRef] [PubMed]

57. Zhao, X.; Sun, G.; Zhang, H.; Ting, S.-M.; Song, S.; Gonzales, N.; Aronowski, J. Polymorphonuclear Neutrophil in Brain Parenchyma After Experimental Intracerebral Hemorrhage. Transl. Stroke Res. 2014, 5, 554-561. [CrossRef] [PubMed]

58. Clark, R.S.B.; Kochanek, P.M.; Schwarz, M.A.; Schiding, J.K.; Turner, D.S.; Chen, M.; Carlos, T.M.; Watkins, S.C. Inducible Nitric Oxide Synthase Expression in Cerebrovascular Smooth Muscle and Neutrophils after Traumatic Brain Injury in Immature Rats. Pediatr. Res. 1996, 39, 784-790. [CrossRef] [PubMed]

59. Carlos, T.M.; Clark, R.S.B.; Franicola-Higgins, D.; Schiding, J.K.; Kochanek, P. Expression of endothelial adhesion molecules and recruitment of neutrophils after traumatic brain injury in rats. J. Leukoc. Biol. 1997, 61, 279-285. [CrossRef] [PubMed]

60. Steffen, B.J.; Breier, G.; Butcher, E.C.; Schulz, M.; Engelhardt, B. ICAM-1, VCAM-1, and MAdCAM-1 are expressed on choroid plexus epithelium but not endothelium and mediate binding of lymphocytes in vitro. Am. J. Pathol. 1996, 148, 1819-1838. [PubMed] 
61. Allport, J.R.; Ding, H.; Collins, T.; Gerritsen, M.E.; Luscinskas, F.W. Endothelial-dependent mechanisms regulate leukocyte transmigration: A process involving the proteasome and disruption of the vascular endothelial-cadherin complex at endothelial cell-to-cell junctions. J. Exp. Med. 1997, 186, 517-527. [CrossRef]

62. Grossetete, M.; Phelps, J.; Arko, L.; Yonas, H.; Rosenberg, G.A. Elevation of Matrix Metalloproteinases 3 And 9 In Cerebrospinal Fluid And Blood In Patients With Severe Traumatic Brain Injury. Neurosurgery 2009, 65, 702-708. [CrossRef]

63. Suzuki, Y.; Matsumoto, Y.; Ikeda, Y.; Kondo, K.; Ohashi, N.; Umemura, K. SM-20220, a Na(+)/H(+) exchanger inhibitor: Effects on ischemic brain damage through edema and neutrophil accumulation in a rat middle cerebral artery occlusion model. Brain Res. 2002, 945, 242-248. [CrossRef]

64. Shultz, S.R.; Bao, F.; Weaver, L.C.; Cain, D.P.; Brown, A. Treatment with an anti-CD11d integrin antibody reduces neuroinflammation and improves outcome in a rat model of repeated concussion. J. Neuroinflamm. 2013, 10, 793. [CrossRef] [PubMed]

65. Mukherjee, S.; Sivakumar, G.; Goodden, J.R.; Tyagi, A.K.; Chumas, P.D. Prognostic value of leukocytosis in pediatric traumatic brain injury. J. Neurosurg. Pediatr. 2021, 27, 335-345. [CrossRef] [PubMed]

66. Dolmans, R.G.; Hulsbergen, A.F.; Gormley, W.B.; Broekman, M.L. Routine Blood Tests for Severe Traumatic Brain Injury: Can They Predict Outcomes? World Neurosurg. 2020, 136, e60-e67. [CrossRef]

67. Wolach, B.; Sazbon, L.; Gavrieli, R.; Broda, A.; Schlesinger, M. Early immunological defects in comatose patients after acute brain injury. J. Neurosurg. 2001, 94, 706-711. [CrossRef] [PubMed]

68. Petrone, A.B.; Gionis, V.; Giersch, R.; Barr, T.L. Immune biomarkers for the diagnosis of mild traumatic brain injury. NeuroRehabilitation 2017, 40, 501-508. [CrossRef]

69. Dreßler, J.; Hanisch, U.; Kuhlisch, E.; Geiger, K.D. Neuronal and glial apoptosis in human traumatic brain injury. Int. J. Leg. Med. 2007, 121, 365-375. [CrossRef] [PubMed]

70. Daglas, M.; Draxler, D.F.; Ho, H.; McCutcheon, F.; Galle, A.; Au, A.; Larsson, P.; Gregory, J.; Alderuccio, F.; Sashindranath, M.; et al. Activated CD8+ T Cells Cause Long-Term Neurological Impairment after Traumatic Brain Injury in Mice. Cell Rep. 2019, 29, 1178-1191.e6. [CrossRef] [PubMed]

71. Fee, D.; Crumbaugh, A.; Jacques, T.; Herdrich, B.; Sewell, D.; Auerbach, D.; Piaskowski, S.; Hart, M.N.; Sandor, M.; Fabry, Z. Activated/effector CD4+ T cells exacerbate acute damage in the central nervous system following traumatic injury. J. Neuroimmunol. 2003, 136, 54-66. [CrossRef]

72. Fukuzuka, K.; Edwards, C.K.; Clare-Salzler, M.; Copeland, E.M.; Moldawer, L.L.; Mozingo, D.W. Glucocorticoid-induced, caspa-se-dependent organ apoptosis early after burn injury. Am. J. Physiol. Regul. Integr. Comp. Physiol. 2000, 278 , R1005-R1018. [CrossRef] [PubMed]

73. Mencl, S.; Hennig, N.; Hopp, S.; Schuhmann, M.K.; Albert-Weissenberger, C.; Sirén, A.-L.; Kleinschnitz, C. FTY720 does not protect from traumatic brain injury in mice despite reducing posttraumatic inflammation. J. Neuroimmunol. 2014, 274, 125-131. [CrossRef] [PubMed]

74. Hillhouse, E.E.; Lesage, S. A comprehensive review of the phenotype and function of antigen-specific immunoregulatory double negative T cells. J. Autoimmun. 2013, 40, 58-65. [CrossRef] [PubMed]

75. Meng, H.; Zhao, H.; Cao, X.; Hao, J.; Zhang, H.; Liu, Y.; Zhu, M.-S.; Fan, L.; Weng, L.; Qian, L.; et al. Double-negative T cells remarkably promote neuroinflammation after ischemic stroke. Proc. Natl. Acad. Sci. USA 2019, 116, 5558-5563. [CrossRef]

76. Braun, M.; Khan, Z.T.; Khan, M.B.; Kumar, M.; Ward, A.; Achyut, B.R.; Arbab, A.S.; Hess, D.C.; Hoda, N.; Baban, B.; et al. Selective activation of cannabinoid receptor-2 reduces neuroinflammation after traumatic brain injury via alternative macrophage polarization. Brain Behav. Immun. 2018, 68, 224-237. [CrossRef] [PubMed]

77. Kostulas, N.; Pelidou, S.H.; Kivisäkk, P.; Kostulas, V.; Link, H. Increased IL-1 $\beta$, IL-8, and IL-17 mRNA Expression in Blood Mononuclear Cells Observed in a Prospective Ischemic Stroke Study. Stroke 1999, 30, 2174-2179. [CrossRef]

78. Kostulas, N.; Kivisäkk, P.; Huang, Y.; Matusevicius, D.; Kostulas, V.; Link, H. Ischemic Stroke Is Associated with a Systemic Increase of Blood Mononuclear Cells Expressing Interleukin-8 mRNA. Stroke 1998, 29, 462-466. [CrossRef]

79. Brait, V.H.; Arumugam, T.; Drummond, G.; Sobey, C.G. Importance of T Lymphocytes in Brain Injury, Immunodeficiency, and Recovery after Cerebral Ischemia. Br. J. Pharmacol. 2012, 32, 598-611. [CrossRef] [PubMed]

80. Wo, J.; Zhang, F.; Li, Z.; Sun, C.; Zhang, W.; Sun, G. The Role of Gamma-Delta T Cells in Diseases of the Central Nervous System. Front. Immunol. 2020, 11, 580304. [CrossRef] [PubMed]

81. Tobin, R.P.; Mukherjee, S.; Kain, J.M.; Rogers, S.K.; Henderson, S.K.; Motal, H.L.; Rogers, M.K.N.; Shapiro, L.A. Traumatic brain injury causes selective, CD74-dependent peripheral lymphocyte activation that exacerbates neurodegeneration. Acta Neuropathol. Commun. 2014, 2, 143. [CrossRef]

82. Newell-Rogers, M.K.; Rogers, S.K.; Tobin, R.P.; Mukherjee, S.; Shapiro, L.A. Antagonism of Macrophage Migration Inhibitory Factory (MIF) after Traumatic Brain Injury Ameliorates Astrocytosis and Peripheral Lymphocyte Activation and Expansion. Int. J. Mol. Sci. 2020, 21, 7448. [CrossRef] [PubMed]

83. Hausmann, R.; Kaiser, A.; Lang, C.; Bohnert, M.; Betz, P. A quantitative immunohistochemical study on the time-dependent course of acute inflammatory cellular response to human brain injury. Int. J. Leg. Med. 1999, 112, 227-232. [CrossRef] [PubMed]

84. Mrakovcic-Sutic, I.; Tokmadzic, V.S.; Laskarin, G.; Mahmutefendic, H.; Lucin, P.; Zupan, Z.; Sustic, A. Early changes in frequency of peripheral blood lymphocyte subpopulations in severe traumatic brain-injured patients. Scand. J. Immunol. 2010, 72, 57-65. [CrossRef] [PubMed] 
85. Joachim, R.A.; Kuhlmei, A.; Dinh, Q.T.; Handjiski, B.; Fischer, T.; Peters, E.M.J.; Klapp, B.F.; Paus, R.; Arck, P.C. Neuronal plasticity of the "brain-skin connection": Stress-triggered up-regulation of neuropeptides in dorsal root ganglia and skin via nerve growth factor-dependent pathways. J. Mol. Med. 2007, 85, 1369-1378. [CrossRef] [PubMed]

86. Dantzer, R. Neuroimmune Interactions: From the Brain to the Immune System and Vice Versa. Physiol. Rev. 2018, 98, 477-504. [CrossRef] [PubMed]

87. Dinet, V.; Petry, K.G.; Badaut, J. Brain-Immune Interactions and Neuroinflammation After Traumatic Brain Injury. Front. Neurosci. 2019, 13, 1178. [CrossRef] [PubMed]

88. Huang, Z.; Fu, Z.; Huang, W.; Huang, K. Prognostic value of neutrophil-to-lymphocyte ratio in sepsis: A meta-analysis. Am. J. Emerg. Med. 2020, 38, 641-647. [CrossRef] [PubMed]

89. Juul, N.; Morris, G.F.; Marshall, S.B.; Marshall, L.F. Intracranial hypertension and cerebral perfusion pressure: Influence on neurological deterioration and outcome in severe head injury. J. Neurosurg. 2000, 92, 1-6. [CrossRef]

90. Laird, A.M.; Miller, P.R.; Kilgo, P.D.; Meredith, J.W.; Chang, M.C. Relationship of early hyperglycemia to mortality in trauma pa-tients. J. Trauma Acute Care Surg. 2004, 56, 1058-1062. [CrossRef] [PubMed]

91. Van Den Berghe, G.; Schoonheydt, K.; Becx, P.; Bruyninckx, F.; Wouters, P.J. Insulin therapy protects the central and peripheral nervous system of intensive care patients. Neurology 2005, 64, 1348-1353. [CrossRef] [PubMed]

92. Jennett, B.; Bond, M. Assessment of outcome after severe brain damage. A Practical Scale. Lancet 1975, 305, 480-484. [CrossRef]

93. Chen, W.; Yang, J.; Li, B.; Peng, G.; Li, T.; Li, L.; Wang, S. Neutrophil to Lymphocyte Ratio as a Novel Predictor of Outcome in Patients with Severe Traumatic Brain Injury. J. Head Trauma Rehabil. 2018, 33, E53-E59. [CrossRef] [PubMed]

94. Huang, Y.-L.; Han, Z.-J.; Hu, Z. Red blood cell distribution width and neutrophil to lymphocyte ratio are associated with outcomes of adult subarachnoid haemorrhage patients admitted to intensive care unit. Ann. Clin. Biochem. Int. J. Lab. Med. 2017, 54, 696-701. [CrossRef] [PubMed]

95. Siwicka-Gieroba, D.; Malodobry, K.; Biernawska, J.; Robba, C.; Bohatyrewicz, R.; Rola, R.; Dabrowski, W. The Neutrophil/Lymphocyte Count Ratio Predicts Mortality in Severe Traumatic Brain Injury Patients. J. Clin. Med. 2019, 8, 1453. [CrossRef]

96. Zhao, J.-L.; Du, Z.-Y.; Yuan, Q.; Yu, J.; Sun, Y.-R.; Wu, X.; Li, Z.-Q.; Wu, X.-H.; Hu, J. Prognostic Value of Neutrophil-to-Lymphocyte Ratio in Predicting the 6-Month Outcome of Patients with Traumatic Brain Injury: A Retrospective Study. World Neurosurg. 2019, 124, e411-e416. [CrossRef] [PubMed]

97. Kimball, R.; Shachar, E.; Eyerly-Webb, S.; Patel, D.M.; Spader, H. Using the neutrophil-to-lymphocyte ratio to predict outcomes in pediatric patients with traumatic brain injury. Clin. Neurol. Neurosurg. 2020, 193, 105772. [CrossRef] [PubMed]

98. Giede-Jeppe, A.; Reichl, J.; Sprügel, M.I.; Lücking, H.; Hoelter, P.; Eyüpoglu, I.Y.; Gerner, S.T. Neutrophil-to-lymphocyte ratio as an in-dependent predictor for unfavorable functional outcome in aneurysmal subarachnoid hemorrhage. J. Neurosurg. 2020, 132, 400-407. [CrossRef]

99. Wang, J.-Y.; Zhang, X.-T.; Wang, J.-Q.; Wang, C.-Y.; Zheng, W.-L.; Pan, Z.-M.; Xu, Z.-B.; Li, X.-Y.; Zhang, Y.-B. Admission Neutrophil-Lymphocyte Ratio Predicts Rebleeding Following Aneurismal Subarachnoid Hemorrhage. World Neurosurg. 2020, 138, e317-e322. [CrossRef]

100. Ferro, D.; Matias, M.; Neto, J.; Dias, R.; Moreira, G.; Petersen, N.; Azevedo, E.; Castro, P. Neutrophil-to-Lymphocyte Ratio Predicts Cerebral Edema and Clinical Worsening Early After Reperfusion Therapy in Stroke. Stroke 2021, 52, 859-867. [CrossRef] [PubMed]

101. Świtońska, M.; Piekuś-Słomka, N.; Słomka, A.; Sokal, P.; Żekanowska, E.; Lattanzi, S. Neutrophil-to-Lymphocyte Ratio and Symptomatic Hemorrhagic Transformation in Ischemic Stroke Patients Undergoing Revascularization. Brain Sci. 2020, 10, 771. [CrossRef] [PubMed]

102. Pikija, S.; Sztriha, L.K.; Killer-Oberpfalzer, M.; Weymayr, F.; Hecker, C.; Ramesmayer, C.; Hauer, L.; Sellner, J. Neutrophil to lymphocyte ratio predicts intracranial hemorrhage after endovascular thrombectomy in acute ischemic stroke. J. Neuroinflamm. 2018, 15, 319. [CrossRef] [PubMed]

103. Brooks, S.D.; Spears, C.; Cummings, C.; Vangilder, R.L.; Stinehart, K.R.; Gutmann, L.; Domico, J.; Culp, S.; Carpenter, J.; Rai, A.; et al. Admission neutrophil-lymphocyte ratio predicts 90 day outcome after endovascular stroke therapy. J. NeuroInterventional Surg. 2014, 6, 578-583. [CrossRef] [PubMed]

104. Aly, M.; Abdalla, R.N.; Batra, A.; Shaibani, A.; Hurley, M.C.; Jahromi, B.S.; Potts, M.B.; Ansari, S.A. Follow-up neutrophillymphocyte ratio after stroke thrombectomy is an independent biomarker of clinical outcome. J. NeuroInterventional Surg. 2021, 13, 609-613. [CrossRef] [PubMed]

105. Liu, C.; Xie, J.; Xiao, X.; Li, T.; Li, H.; Bai, X.; Li, Z.; Wang, W. Clinical predictors of prognosis in patients with traumatic brain injury combined with extracranial trauma. Int. J. Med. Sci. 2021, 18, 1639-1647. [CrossRef]

106. Alexiou, G.A.; Lianos, G.D.; Tzima, A.; Sotiropoulos, A.; Nasios, A.; Metaxas, D.; Voulgaris, S. Neutrophil to lymphocyte ratio as a pre-dictive biomarker for computed tomography scan use in mild traumatic brain injury. Biomark. Med. 2020, 14, 1085-1090. [CrossRef] [PubMed]

107. Bilgi, K.; Gopalakrishna, K.N.; Chakrabarti, D.; Rao, G.U. Outcome Prediction of TBI: Are There Parameters That Affect the IMPACT and CRASH Models? World Neurosurg. 2021, 146, e590-e596. [CrossRef] [PubMed]

108. Corbett, J.-M.; Ho, K.M.; Honeybul, S. Prognostic significance of abnormal hematological parameters in severe traumatic brain injury requiring decompressive craniectomy. J. Neurosurg. 2020, 132, 545-551. [CrossRef] [PubMed] 
109. O'Byrne, P.M.; Metev, H.; Puu, M.; Richter, K.; Keen, C.; Uddin, M.; Larsson, B.; Cullberg, M.; Nair, P. Efficacy and safety of a CXCR2 antagonist, AZD5069, in patients with uncontrolled persistent asthma: A randomised, double-blind, placebo-controlled trial. Lancet Respir. Med. 2016, 4, 797-806. [CrossRef]

110. Kang, L.; Yu, H.; Yang, X.; Zhu, Y.; Bai, X.; Wang, R.; Cao, Y.; Xu, H.; Luo, H.; Lu, L.; et al. Neutrophil extracellular traps released by neutrophils impair revascularization and vascular remodeling after stroke. Nat. Commun. 2020, 11, 2488. [CrossRef] [PubMed]

111. Kaur, T.; Dumoga, S.; Koul, V.; Singh, N. Modulating neutrophil extracellular traps for wound healing. Biomater. Sci. 2020, 8 , 3212-3223. [CrossRef]

112. Matlung, H.L.; Szilagyi, K.; Barclay, N.A.; Berg, T.K.V.D. The CD47-SIRP $\alpha$ signaling axis as an innate immune checkpoint in cancer. Immunol. Rev. 2017, 276, 145-164. [CrossRef] [PubMed]

113. Wipke, B.T.; Allen, P.M. Essential Role of Neutrophils in the Initiation and Progression of a Murine Model of Rheumatoid Arthritis. J. Immunol. 2001, 167, 1601-1608. [CrossRef] [PubMed]

114. Bilgin, Y.M.; de Greef, G.E. Plerixafor for stem cell mobilization: The current status. Curr. Opin. Hematol. 2016, $23,67-71$. [CrossRef] [PubMed]

115. Teixidó, J.; Martínez-Moreno, M.; Díaz-Martínez, M.; Sevilla-Movilla, S. The good and bad faces of the CXCR4 chemokine receptor. Int. J. Biochem. Cell Biol. 2018, 95, 121-131. [CrossRef] [PubMed]

116. Campbell, I.K.; Leong, D.; Edwards, K.M.; Rayzman, V.; Ng, M.; Goldberg, G.L.; Wilson, N.J.; Scalzo-Inguanti, K.; MackenzieKludas, C.; Lawlor, K.E.; et al. Therapeutic targeting of the G-CSF receptor reduces neutrophil trafficking and joint inflammation in antibody-mediated inflammatory arthritis. J. Immunol. 2016, 197, 4392-4402. [CrossRef] [PubMed]

117. Mitroulis, I.; Alexaki, V.I.; Kourtzelis, I.; Ziogas, A.; Hajishengallis, G.; Chavakis, T. Leukocyte integrins: Role in leukocyte recruitment and as therapeutic targets in inflammatory disease. Pharmacol. Ther. 2015, 147, 123-135. [CrossRef] [PubMed]

118. Wang, R.; Zhu, Y.; Liu, Z.; Chang, L.; Bai, X.; Kang, L.; Cao, Y.; Yang, X.; Yu, H.; Shi, M.-J.; et al. Neutrophil extracellular traps promote tPA-induced brain hemorrhage via cGAS in mice with stroke. Blood 2021, 138, 91-103. [CrossRef] [PubMed]

119. Giunta, B.; Obregon, D.; Velisetty, R.; Sanberg, P.R.; Borlongan, C.V.; Tan, J. The immunology of traumatic brain injury: A prime target for Alzheimer's disease prevention. J. Neuroinflamm. 2012, 9, 185. [CrossRef]

120. Kara, S.P.; Altunan, B.; Unal, A. Investigation of the peripheral inflammation (neutrophil-lymphocyte ratio) in two neurodegenerative diseases of the central nervous system. Neurol. Sci. 2021. [CrossRef] [PubMed]

121. Zhao, Y.; Yue, J.; Lei, P.; Lin, T.; Peng, X.; Xie, D.; Gao, L.; Shu, X.; Wu, C. Neutrophil-lymphocyte ratio as a predictor of delirium in older internal medicine patients: A prospective cohort study. BMC Geriatr. 2021, 21, 334. [CrossRef]

122. Levochkina, M.; McQuillan, L.; Awan, N.; Barton, D.; Maczuzak, J.; Bianchine, C.; Trombley, S.; Kotes, E.; Wiener, J.; Wagner, A.; et al. Neutrophil-to-Lymphocyte Ratios and Infections after Traumatic Brain Injury: Associations with Hospital Resource Utilization and Long-Term Outcome. J. Clin. Med. 2021, 10, 4365. [CrossRef]

123. Fluiter, K.; Opperhuizen, A.L.; Morgan, B.P.; Baas, F.; Ramaglia, V. Inhibition of the membrane attack complex of the com-plement system reduces secondary neuroaxonal loss and promotes neurologic recovery after traumatic brain injury in mice. J. Immunol. 2014, 192, 2339-2348. [CrossRef] [PubMed]

124. Kovesdi, E.; Kamnaksh, A.; Wingo, D.; Ahmed, F.; Grunberg, N.E.; Long, J.B.; Kasper, C.E.; Agoston, D.V. Acute Minocycline Treatment Mitigates the Symptoms of Mild Blast-Induced Traumatic Brain Injury. Front. Neurol. 2012, 3, 111. [CrossRef]

125. Homsi, S.; Federico, F.; Croci, N.; Palmier, B.; Plotkine, M.; Marchand-Leroux, C.; Jafarian-Tehrani, M. Minocycline effects on cerebral edema: Relations with inflam-matory and oxidative stress markers following traumatic brain injury in mice. Brain Res. 2009, 1291, 122-132. [CrossRef]

126. Ali, T.; Hao, Q.; Ullah, N.; Rahman, S.U.; Shah, F.A.; He, K.; Zheng, C.; Li, W.; Murtaza, I.; Li, Y.; et al. Melatonin Act as an Antidepressant via Attenuation of Neuroinflammation by Targeting Sirt1/Nrf2/HO-1 Signaling. Front. Mol. Neurosci. 2020, 13, 96. [CrossRef] [PubMed]

127. Tajiri, N.; Acosta, S.A.; Shahaduzzaman, M.; Ishikawa, H.; Shinozuka, K.; Pabon, M.; Hernandez-Ontiveros, D.; Kim, D.W.; Metcalf, C.; Staples, M.; et al. Intravenous Transplants of Human Adipose-Derived Stem Cell Protect the Brain from Traumatic Brain Injury-Induced Neurodegeneration and Motor and Cognitive Impairments: Cell Graft Biodistribution and Soluble Factors in Young and Aged Rats. J. Neurosci. 2014, 34, 313-326. [CrossRef] [PubMed]

128. Wu, H.; Mahmood, A.; Lu, D.; Jiang, H.; Xiong, Y.; Zhou, D.; Chopp, M. Attenuation of astrogliosis and modulation of endothelial growth factor receptor in lipid rafts by simvastatin after traumatic brain injury. J. Neurosurg. 2010, 113, 591-597. [CrossRef] [PubMed]

129. Kwiecien, J.M.; Dabrowski, W.; Kwiecien-Delaney, B.J.; Kwiecien-Delaney, C.J.; Siwicka-Gieroba, D.; Yaron, J.R.; Zhang, L.; Delaney, K.H.; Lucas, A.R. Neuroprotective Effect of Subdural Infusion of Serp-1 in Spinal Cord Trauma. Biomedicines $2020,8,372$. [CrossRef] [PubMed]

130. Hüner, E.A.; Dai, A.I.; Demiryürek, A.T. Association of Neutrophil/Lymphocyte Ratio with Intravenous Immunoglobulin Treatment in Children with Guillain-Barré Syndrome. J. Child. Neurol. 2018, 33, 164-167. [CrossRef] [PubMed]

131. Koiwa, M.; Goto, S.; Takahashi, K.; Kamada, T.; Takai, S.; Nakamura, H. Neutrophil/Lymphocyte Ratio in Patients with Rheumatoid Arthritis Treated with Biological Agents. J. Nippon. Med. Sch. 2016, 83, 118-124. [CrossRef] 
132. Hirahara, T.; Arigami, T.; Yanagita, S.; Matsushita, D.; Uchikado, Y.; Kita, Y.; Mori, S.; Sasaki, K.; Omoto, I.; Kurahara, H.; et al. Combined neutrophil-lymphocyte ratio and platelet-lymphocyte ratio predicts chemotherapy response and prognosis in patients with advanced gastric cancer. BMC Cancer 2019, 19, 672. [CrossRef] [PubMed]

133. Gusdon, A.M.; Gialdini, G.; Kone, G.; Baradaran, H.; Merkler, A.E.; Mangat, H.S.; Navi, B.; Iadecola, C.; Gupta, A.; Kamel, H.; et al. Neutrophil-Lymphocyte Ratio and Perihematomal Edema Growth in Intracerebral Hemorrhage. Stroke 2017, 48, $2589-2592$. [CrossRef] [PubMed] 